\title{
Tarimspira from the Cambrian (Series 2, Stage 4) of Laurentia (Greenland): extending the skeletal record of paraconodontid vertebrates
}

\author{
John S. Peel \\ Department of Earth Sciences (Palaeobiology), Uppsala University, Villavägen 16, SE-75236 Uppsala, Sweden 〈john.peel@pal.uu.se〉
}

\begin{abstract}
Phosphatic sclerites of the problematic Tarimspira Yue and Gao, 1992 (Cambrian Series 2) recovered by weak acid maceration of limestones display a unique range of mainly strongly coiled morphologies. They were likely organized into multielement scleritomes, but the nature of these is poorly known; some sclerites may have had a grasping function. Tarimspira sclerites grew by basal accretion in an analogous fashion to younger paraconodonts (Cambrian Series 3-4) but lack a basal cavity. Based on proposed homologies, Tarimspira may provide an extension of the early vertebrate paraconodont-euconodont clade back into the early Cambrian. Tarimspira is described for the first time from Laurentia (North Greenland), extending its known range from China and Siberia in Cambrian Series 2. In addition to the type species, Tarimspira plana Yue and Gao, 1992, the Greenland record of Tarimspira includes two morphotypes of a new species, Tarimspira artemi.
\end{abstract}

UUID: http://zoobank.org /c7c536c8-cdaf-49a9-ae1d-77c392f553fc.

\section{Introduction}

The discovery and description of the conodont animal from the Carboniferous of Scotland (Briggs et al., 1983) inevitably stimulated discussion concerning the relationship of conodonts to early vertebrates (Aldridge et al., 1986, 1993; Kemp and Nichol, 1995; Donoghue et al., 1998, 2000; Blieck et al., 2010; Turner et al., 2010; Donoghue and Keating, 2014). In these deliberations, the main focus of discussion was on euconodonts, the most familiar of the three descriptive groups (protoconodonts, paraconodonts, euconodonts) recognized on the basis of mainly Cambrian material by Bengtson (1983). The affinity of protoconodonts with chaetognaths rather than vertebrates was established by Szaniawski (1982, 1983, 1987, 2002; Vannier et al., 2007), but Bengtson's (1983) suggestion that euconodonts were derived from paraconodonts ultimately formed the focus for the investigation of conodont element structure between these latter two groups by Murdock et al. (2013, 2014). Similarity between the crown tissue of euconodont elements and vertebrate enamel was attributed to convergence rather than homology (Murdock et al., 2013, 2014), although the vertebrate affinity of conodonts was not questioned. Donoghue and Keating (2014) accepted the conclusions of Murdock et al. (2013) while maintaining assignment of conodonts to the vertebrates on the basis of their soft part anatomy (Aldridge et al., 1993; Pridmore et al., 1997), despite the objections of Blieck et al. (2010) and Turner et al. (2010).

Microscopic, coiled, phosphatic early Cambrian sclerites described herein show little overall morphological similarity to the diverse and widely distributed conodont elements recovered from Cambrian-Triassic sediments. Their extraordinary mode of growth indicates, however, that they can be compared to some Cambrian (Series 3-4) paraconodonts, and this observation is developed to promote a tentative extension of the model of early vertebrate (conodont) evolution proposed by Murdock et al. (2013) back into the early Cambrian (Cambrian Series 2).

The Cambrian sclerites are assigned to Tarimspira Yue and Gao, 1992. The type species, Tarimspira plana Yue and Gao, 1992, was originally described from the lower Cambrian (Cambrian Series 2) of western China and is unusual because of its tightly coiled, laterally compressed, planispiral form (Fig. 1). Yue and Gao (1992) compared its shape with that of bellerophontiform mollusks, and there is a seductive resemblance to isostrophically coiled shells of macromolluskan genera such as Joleaudella Patte, 1929. However, leaving aside the great difference in size, geological age, and phosphatic composition, examination of the method of shell accretion of Tarimspira quickly demonstrates that the similarity is superficial, as recognized by Yue and Gao (1992), merely reflecting their common logarithmic growth. Tarimspira plana is a relatively solid sclerite with externally deposited growth lamellae that extend from the base to envelop the lateral surfaces. While this method of accretion is also seen in the early growth stages of paraconodonts, the latter rapidly develop a conical form and a deep basal cavity during ontogeny that is not present in Tarimspira (Müller, 1959; Andres, 1988; Müller and Hinz, 1991; Murdock et al., 2013).

Tarimspira is documented herein from several horizons within the lower Cambrian (Cambrian Series 2, Stage 4) of North Greenland (Fig. 2), where it is represented by Tarimspira artemi $\mathrm{n}$. sp. and a single specimen of the type species, Tarimspira plana. The occurrences represent its first description from Laurentia, consolidating a brief identification (as Fengzuella) by 


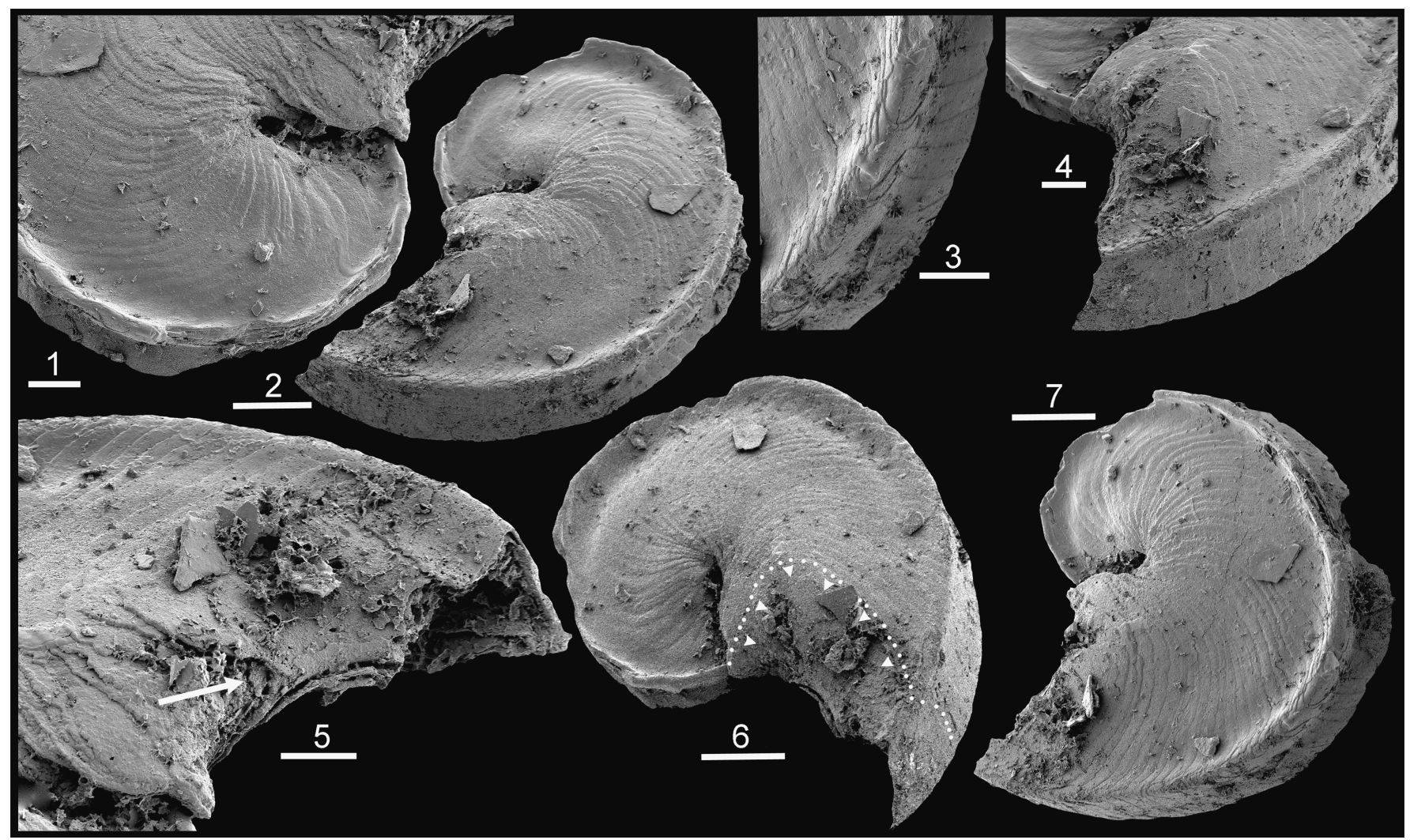

Figure 1. Tarimspira plana Yue and Gao, 1992, PMU 31847 from GGU sample 255522, Aftenstjernesø Formation (Cambrian Series 2, Stage 4), Løndal, Peary Land, North Greenland. (1) Detail of umbilical region and growth lamellae; $(\mathbf{2}, \mathbf{7})$ oblique lateral views showing peripheral keels; (3) detail of peripheral keels; $(\mathbf{4}, \mathbf{5})$ latest growth stage showing last deposited growth lamella extending from base onto lateral areas (arrow in 5); (6) slightly oblique lateral showing extent of last deposited growth lamella and its direction of slope (arrows). (1, 3-5) Scale bars $=50 \mu \mathrm{m} ;(\mathbf{2}, \mathbf{6}, \mathbf{7})$ scale bars $=100 \mu \mathrm{m}$.

Kouchinsky et al. (2015, p. 481). Tarimspira has previously been described from Siberia (Kouchinsky et al., 2015) and several terranes in China (Yue and Gao, 1992; Steiner et al., 2003; Yang et al., 2015). Although few, these currently known occurrences display a clear equatorial distribution (Fig. 2.4).

Steiner et al. (2003) commented that Chinese specimens occurred in marginal shelf environments. This pattern is confirmed by the present records from shelf deposits of the Aftenstjernes $\emptyset$ and Henson Gletscher formations of North Greenland (Ineson and Peel, 1997; Fig. 2.3).

Steiner et al. (2003) recognized that the co-occurrence of Tarimspira (as Fengzuella) zhejiangensis (He and $\mathrm{Yu}, 1992)$ with two other sclerite morphotypes in samples from South China indicated that it formed part of the scleritome of an undetermined organism. This deduction is confirmed herein with the description of a new species, Tarimspira artemi, from the Henson Gletscher Formation of North Greenland in which two sclerite morphotypes are known currently from the scleritome. Tarimspira artemi $\mathrm{n}$. sp. is also recorded from the Emyaksin Formation (Cambrian Series 2, Stage 3) of northern Siberia, where it was described under the name Fengzuella zhejiangensis by Kouchinsky et al. (2015). Tarimspira plana, originally described from the Tarim terrane of western China (Yue and Gao, 1992), is now described from the basal Aftenstjernes $\emptyset$ Formation of Peary Land, North Greenland (Figs. 1, 2); this species also appears to contain at least two sclerite morphotypes in its scleritome.

\section{Geological background and materials}

The geological evolution and lithostratigraphy of the Cambrian of North Greenland were described by Higgins et al. (1991) and Ineson and Peel $(1997,2011)$. Siliciclastic shelf sediments of the Buen Formation (Cambrian Series 2, Stages 3-4; Fig. 2.3) are overlain by carbonates (Aftenstjernes $\varnothing$ Formation) that represent the initial stage in the establishment of a major carbonate platform that extended east-west across North Greenland during the Cambrian-Silurian. In the Freuchen Land and Peary Land region (Fig. 2.2), the Cambrian carbonates form a northward prograding complex in which recessive units of dark carbonates and shales (Henson Gletscher, Ekspedition Bræ, and Holm Dal formations; Fig. 2.3), representing periods of relative lowstand of sea level, are separated by carbonate turbidites and mass flow deposits (Aftenstjernes $\varnothing$, Sydpasset, and Fimbuldal formations; Fig. 2.3) deposited during periods of sea level highstand (Ineson and Peel, 1997).

Material of Tarimspira from North Greenland was collected from the Aftenstjernes $\emptyset$ and Henson Gletscher formations (early Cambrian; Cambrian Series 2, Stage 4; Fig. 2.3). In Peary Land and Freuchen Land, the Aftenstjernes $\varnothing$ Formation yields fossils only from its basal member, a widespread, sediment-starved, outer ramp sequence in which hardgrounds are conspicuous (Frykman, 1980; Ineson and Peel, 1997; Peel, 2017). The member is $3-7 \mathrm{~m}$ thick and is mainly composed of glauconitic and phosphatic dolostones 

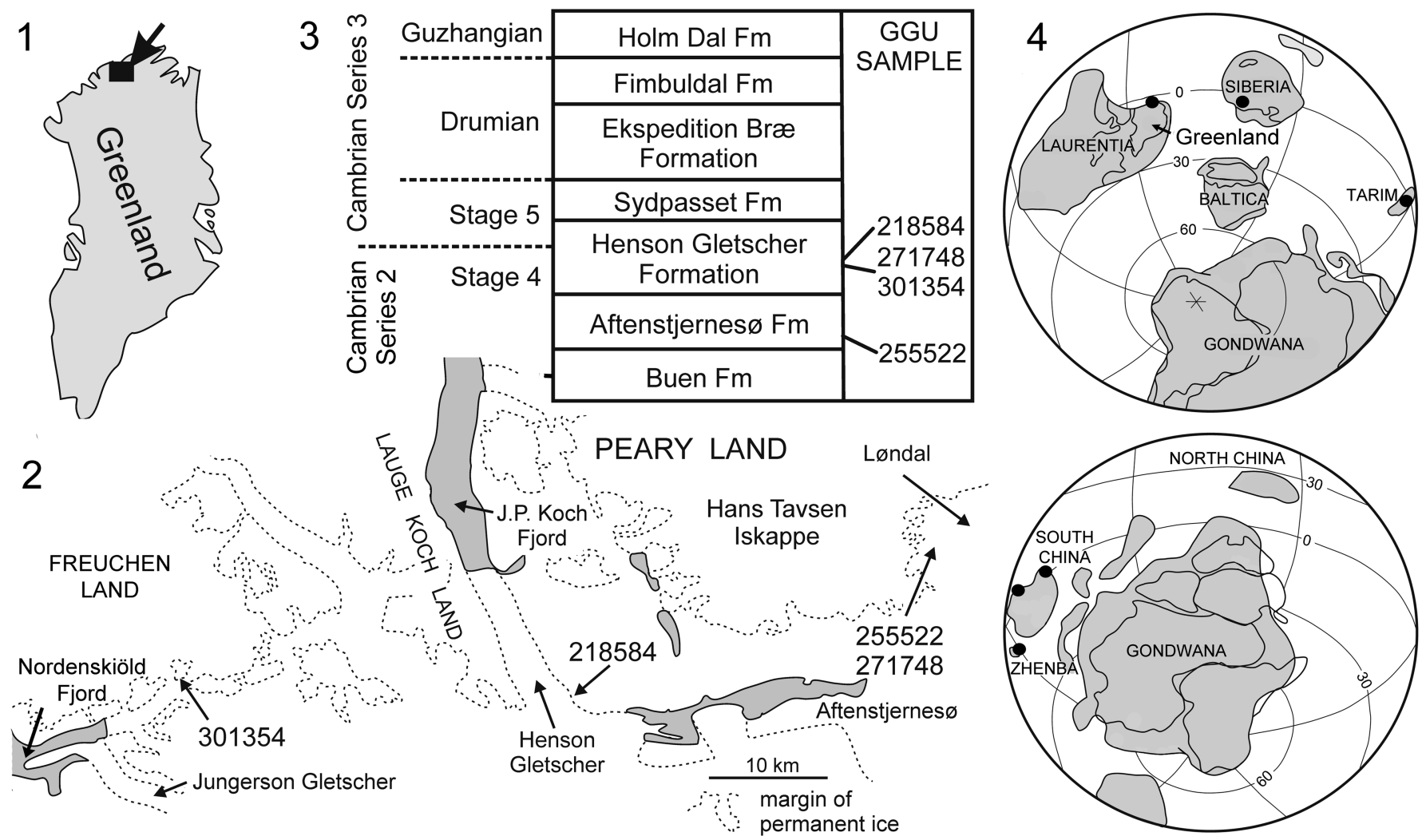

Figure 2. (1, 2) Collection localities of GGU samples from North Greenland yielding Tarimspira; (3) Cambrian stratigraphy in the Freuchen Land-Peary Land region with derivation of samples; (4) distribution of Tarimspira during Cambrian Series 2.

and limestones that vary in texture from massive to laminated and burrowed.

The Henson Gletscher Formation is dominated by thinly bedded, sooty black limestones, dolostones, and shales that were deposited in an off-platform setting (Higgins et al., 1991; Ineson and Peel, 1997; Geyer and Peel, 2011). In most sections, a lower dark recessive member is overlain by a prominent median unit of pale sandstones and a recessive upper dark member. Diverse faunas (Cambrian Series 2, Stage 4) from the Henson Gletscher Formation were monographed by Blaker and Peel (1997), Geyer and Peel (2011), and Peel et al. (2016). Trilobites of Cambrian Series 3 age were described by Robison (1984) and Babcock (1994a, b).

Samples were collected during regional mapping campaigns (1978-1980; 1984-1985) of the Geological Survey of Greenland (Peel and Sønderholm, 1991). Specimens were etched from the limestone with $10 \%$ acetic acid, hand picked from sieved fractions ( $250 \mu \mathrm{m}$ and coarser), and gold-coated prior to scanning electron microscopy. Images were assembled in Adobe Photoshop CS4.

Locality information.-GGU sample 255522 was collected by P. Frykman on 14 July 1979 from limestone within the lowest $1 \mathrm{~m}$ of the basal member of the Aftenstjernes $\varnothing$ Formation in Løndal, Peary Land $\left(82^{\circ} 17.5^{\prime} \mathrm{N}, 37^{\circ} 03^{\prime} \mathrm{W}\right.$; Fig. 2).

GGU sample 301354 was collected by J.S. Peel on 17 August 1985 from the lower member of the Henson Gletscher Formation on a nunatak in southern Freuchen Land $\left(82^{\circ} 10.5^{\prime} \mathrm{N}\right.$, $42^{\circ} 09^{\prime} \mathrm{W}$; Fig. 2). GGU sample 271748 was collected by J.S. Peel on 16 July 1978 from about $3 \mathrm{~m}$ below the median sandstone member of the Henson Gletscher Formation, Løndal, Peary Land $\left(82^{\circ} 17.5^{\prime} \mathrm{N}, 37^{\circ} 03^{\prime} \mathrm{W}\right.$; Fig. 2). The sample is located in the stratigraphic section illustrated by Peel et al. (2016, fig. 2A). GGU sample 218584 was collected by J.R. Ineson on 28 July 1979 in southwest Peary Land, at the head of Henson Gletscher $\left(82^{\circ} 10^{\prime} \mathrm{N}, 39^{\circ} 40^{\prime} \mathrm{W}\right.$; Geyer and Peel 2011, fig. 1D, E, locality 5; Blaker and Peel, 1997, fig. 8A, locality 4) from immediately below sandstones forming the upper $13 \mathrm{~m}$ of the formation (Fig. 2).

Repositories and institutional abbreviations.-GGU prefix indicates a sample collected during field work by Grønlands Geologiske Undersøgelse (Geological Survey of Greenland), now a part of the Geological Survey of Denmark and Greenland, Copenhagen. Type and figured specimens from Greenland (PMU prefix) are deposited in the paleontological type collection of the Museum of Evolution, Uppsala University. Other repositories are noted in the text.

\section{Systematic paleontology}

\section{Genus Tarimspira Yue and Gao, 1992}

1992 Tarimspira Yue and Gao, p. 153.

1992 Fengzuella He and Yu, p. 5, non-Fengzuella Li and Han, 1980. 
1992 Otoformilites Qin and Li in Ding et al., p. 89.

2003 Fengzuella; Steiner et al., p. 858.

2015 Fengzuella; Kouchinsky et al., p. 479.

2015 Tarimspira; Yang et al. 2015, p. 1561.

Type species.-Tarimspira plana Yue and Gao, 1992 from the Aksu-Wushi region, Xinjiang, China.

Diagnosis.-Sclerites varying from bilaterally symmetrical, laterally compressed, planispirally coiled with up to three whorls, through shallowly curved and laterally compressed, to almost straight with circular cross section. Coiled morphotypes open coiled or with whorls in contact, often with a spiral keel or carina, or a shallow spiral depression, on periphero-lateral areas. Multilayered with growth lamellae overlapping lateral areas from the basal (abapical) surface. Lamellae compact externally but may be only loosely in contact internally, with cavities, and possibly a circumperipheral canal.

Occurrence.-Cambrian Series 2 of China, Siberia, and Laurentia (Fig. 2.4).

Remarks.-The diagnosis of Steiner et al. (2003), itself an emendation, is abbreviated and modified to take account of the greater number of whorls in sclerites of Tarimspira artemi $\mathrm{n}$. sp. Furthermore, the central cavity is not present in all sclerites assigned to Tarimspira herein.

Steiner et al. (2003) synonymized Tarimspira Yue and Gao, 1992 and Otoformilites Qin and Li in Ding et al., 1992 with Fengzuella $\mathrm{He}$ and $\mathrm{Yu}, 1992$ following analysis of the dates of their publication. The latter genus, however, is a junior homonym of Fengzuella Li and Han, 1980 that prompted Yang et al. (2015) to propose Tarimspira as a replacement name for Fengzuella He and Yu, 1992. Ironically, both Li and Han (1980) and $\mathrm{He}$ and $\mathrm{Yu}$ (1992) also employed zhejiangensis as the species-group epithet for their respective genera. On account of this species-group homonymy, Yang et al. (2015) gave taxonomic priority to Tarimspira plana Yue and Gao, 1992, considering the entire combination Fengzuella zhejiangensis $\mathrm{He}$ and $\mathrm{Yu}, 1992$ to be invalid. However, application of International Code of Zoological Nomenclature (ICZN) article 57.8.1 states that "Homonymy between identical species-group names in combination (originally or subsequently) with homonymous generic names having the same spelling but established for different nominal genera is to be disregarded" (International Commission on Zoological Nomenclature, 1999, 2012). Fengzuella Li and Han, 1980, an Ordovician brachiopod, and Fengzuella He and Yu, 1992, a problematic Cambrian sclerite, are different nominal genera with the consequence that Tarimspira zhejiangensis ( $\mathrm{He}$ and $\mathrm{Yu}, 1992$ ) is a valid name. It is employed in the present context for specimens described by Steiner et al. (2003) from Zhejiang.

Contrary to the opinion of Steiner et al. (2003), Tarimspira plana Yue and Gao, 1992 is not considered to be a junior synonym of Tarimspira zhejiangensis (He and $\mathrm{Yu}, 1992$ ). Furthermore, the collective synonymization under Tarimspira plana proposed by Yang et al. (2015) is not accepted.

The vitreous, translucent, phosphatic composition of specimens from Greenland suggests that Tarimspira sclerites

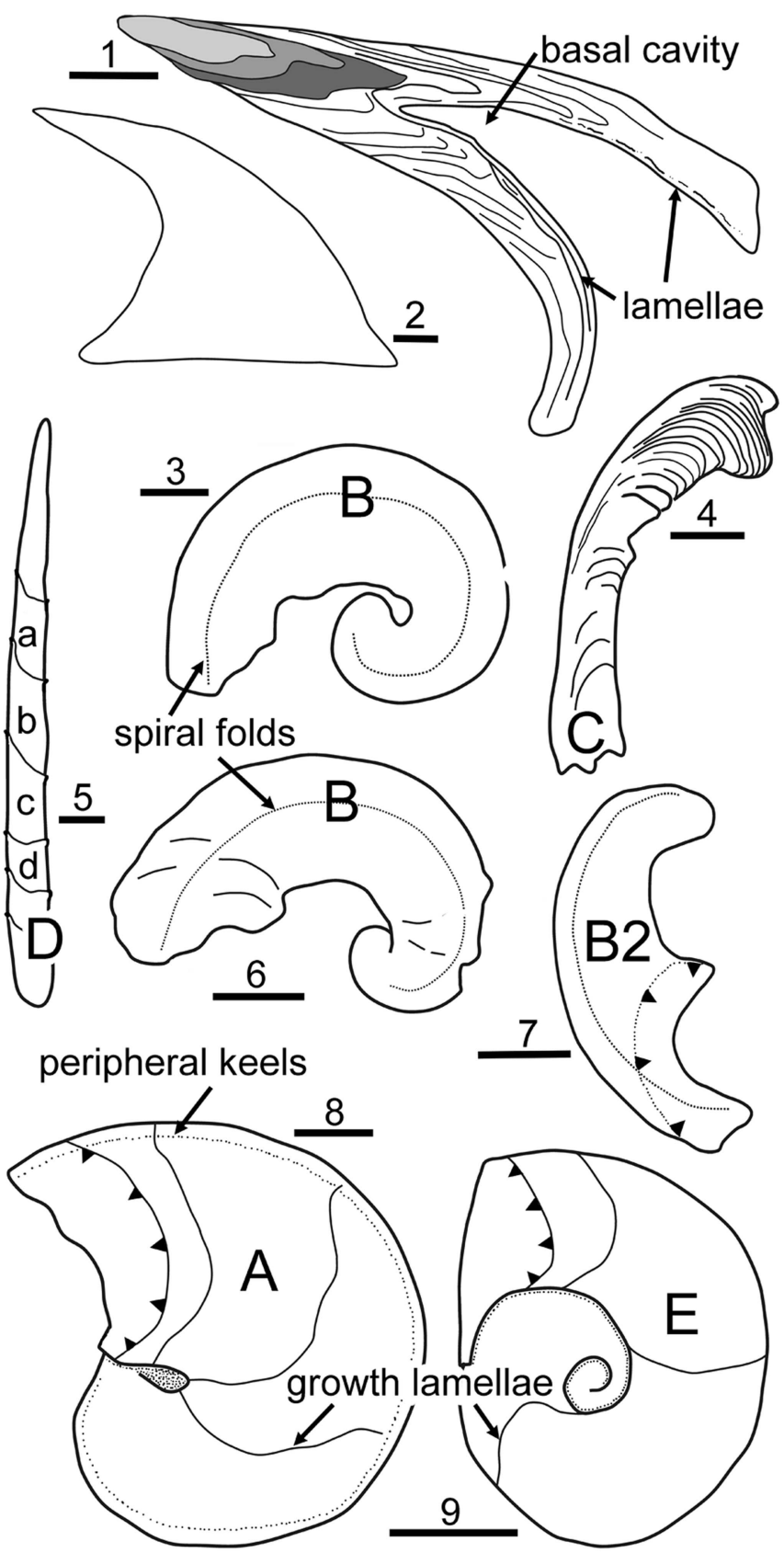

Figure 3. (1, 2) Problematoconites, cross section and outline of complete paraconodont element from the Windfall Formation, Ordovician (Tremadocian), Nevada, USA, showing early growth stages (shaded) with basal growth lamellae overlapping lateral areas and lamellae that subsequently traverse the entire basal cavity (sketched after Murdock et al. 2013). (3-6) Tarimspira zhejiangensis (He and Yu, 1992), early Cambrian, Zhejiang, China, sketched from photographs by Steiner et al. (2003); (3) holotype of Fengzuella zhejiangensis $\mathrm{He}$ and $\mathrm{Yu}, 1992$, specimen 89-11-2-2452 in the Nanjing Institute of Geology and Palaeontology, China, morphotype B, Hetang Formation; (4) morphotype C, Dui2-1-12, chert unit beneath Hetang Formation; (5) morphotype D, showing overlapping lamellae (a-d, oldest to youngest) sketched from Dui2-2-7a and Dui2-2-26, chert unit beneath Hetang Formation; (6) morphotype B, 133-2-15, chert unit beneath Hetang Formation. Specimens other than the holotype are deposited in the Technical University (Berlin). (7, 9) Tarimspira artemi n. sp., Henson Gletscher Formation, North Greenland, with adapical margin of latest growth lamella marked with arrow heads; (7) morphotype B2; (9) morphotype E. (8) Tarimspira plana Yue and Gao, 1992, Aftenstjernes $\emptyset$ Formation, North Greenland, morphotype E, with adapical margin of latest growth lamella marked with arrow heads. (1, 3-9) Scale bars $=50 \mu \mathrm{m}$; (2) scale bar $=100 \mu \mathrm{m}$. 
were composed of primary calcium phosphate. Steiner et al. (2003) and Kouchinsky et al. (2015) suggested that Tarimspira phosphatized remains may have been originally unmineralized, as proposed for early Cambrian protoconodonts by Slater et al. (2018).

\section{Tarimspira plana Yue and Gao, 1992 Figure 1}

1992 Tarimspira plana Yue and Gao, 1992, p. 153, pl. 5, figs. 7-9.

2015 Tarimspira plana; Yang et al., p. 1561, fig. 10O, P.

Holotype.-Specimen 33055/BH7-3a, illustrated by Yue and Gao (1992, pl. 5, fig. 9a, b), Xiaoerbulak Formation (Cambrian Series 2, Stage 4), Aksu-Wushi Region, Tarim Basin, Xinjiang, northwest China (repository unknown).

Diagnosis.—Tightly coiled, planispiral, and bilaterally symmetrical, with a pair of peripheral keels.

Description.-The laterally compressed, planispiral, bilaterally symmetrical sclerite is tightly but uniformly coiled through about one and a quarter whorls. Shallowly convex lateral surfaces become concave prior to their transition into a pair of robust spiral keels, located at the periphery, one on each side of the plane of symmetry. The peripheral keels become reduced in relief at the latest growth stage. They delimit a median channel that is slightly V-shaped in transverse profile, with shallowly convex sides, in the early growth stages (Fig. 1.3) but becomes flattened at the latest growth stage (Fig. 1.4). Adaxially, each lateral surface curves abruptly into a deep narrow umbilicus formed as the growing sclerite overlaps earlier growth stages. At the latest growth stage, the sutural area between the enveloping whorl and the earlier growth stage consists of a deep invagination, with the latest growth lamellae not in direct contact with the earlier whorl (Fig. 1.1).

Externally, the sclerite is compact and appears to be solid, formed by a series of lamellae that slope obliquely abapically in from the lateral areas toward the axial plane in the direction of growth. Thus, the latest growth lamella forms a continuous surface that curves around the growing margin of the sclerite from one lateral area to the other (Fig. 1.5, arrow). The lamellae produce regular transverse lines of growth that are concave toward the direction of growth of the sclerite.

Materials.-PMU 31847 from GGU sample 255522, Aftenstjernesø Formation, Cambrian Series 2, Stage 4, Løndal, Peary Land, North Greenland.

Remarks.-In following discussion, the morphology of this sclerite is referred to as morphotype A (Fig. 3.8).

The embracive synonymy of previously described taxa with Tarimspira plana Yue and Gao, 1992 proposed by Yang et al. (2015) is not accepted. Yue and Gao (1992) described Tarimspira plana from the lowermost beds of the Xiaoerbulak Formation. Two of the specimens illustrated by Yue and Gao (1992, pl. 5, figs. 8, 9) show the bilaterally symmetrical form of the Greenland specimen. In a third specimen, the keels are displaced to one side and bilateral symmetry is lost, suggesting that this may be a second sclerite type within the scleritome.

While the outer surface of the only known specimen from Greenland is compact, the broken peripheral tip at the latest growth stage reveals an inner cavity within several widely spaced lamellae (Fig. 1.5). It is not known whether this cavity is partly original or a function of preservation. Steiner et al. (2003) described similar loose contact between internal lamellae in Tamispira zhenjaingensis and inferred the presence of a peripheral internal canal, discussed in the folllowing.

The holotype illustrated by Yue and Gao (1992) from the Xiaoerbulak Formation (Cambrian Series 2, Stage 4) of the Aksu-Wushi region of Xinjiang, northwest China, is twice the length of the single sclerite known from the Aftenstjernes $\varnothing$ Formation. Two specimens illustrated by Yang et al. (2015) from the Shuijingtuo Formation (Cambrian Series 2, Stage 3) of South China are even larger. In one of these (Yang et al., 2015, fig. 10P), the whorl uncoils in its latest fraction. Coiling becomes tighter in the other specimen, occluding the umbilici (Yang et al., 2015, fig. 10O), but it seems likely that this may be a variable character.

\section{Tarimspira zhejiangensis ( $\mathrm{He}$ and $\mathrm{Yu}, 1992)$} Figure 3.3-3.6

1992 Fengzuella zhejiangensis $\mathrm{He}$ and Yu, p. 5, pl. 2, fig. 17 non-Fengzuella zhejiangensis $\mathrm{Li}$ and Han, 1980.

2003 Fengzuella zhejiangensis; Steiner et al., p. 38, fig. 3a, b, p, q.

Holotype.-Specimen number 89-11-2-2452 in the Nanjing Institute of Geology and Palaeontology illustrated by $\mathrm{He}$ and $\mathrm{Yu}$ (1992) and by Steiner et al. (2003, fig. 3a, b) from the Hetang Formation, Jiangshan County, Zhejiang Province, China.

Remarks.-Steiner et al. (2003) described three types of sclerite (here referred to as morphotypes B-D; Fig. 3) within the scleritome of Tarimspira zhejiangensis (as Fengzuella zhejiangensis). The eponymous sclerite (morphotype B; Fig. 3.3, 3.6) is rare in the assemblages from the Hetang Formation. They are dominated numerically by sclerites of morphotype C (Fig. 3.4), which can be considered to characterize the scleritome.

\section{Tarimspira artemi new species} Figures 4, 5

2015 Fengzuella zhejiangensis; Kouchinsky et al., p. 479, fig. 54.

Holotype.-PMU 31848 from GGU sample 301354, Henson Gletscher Formation, Cambrian Series 2, Stage 4, southern Freuchen Land, North Greenland.

Diagnosis.—Laterally compressed, planispiral, bilaterally symmetrical sclerite that is tightly but uniformly coiled through about one and a half to three whorls; lateral areas shallowly concave, without spiral keels or carinae (based on sclerite morphotype E). 


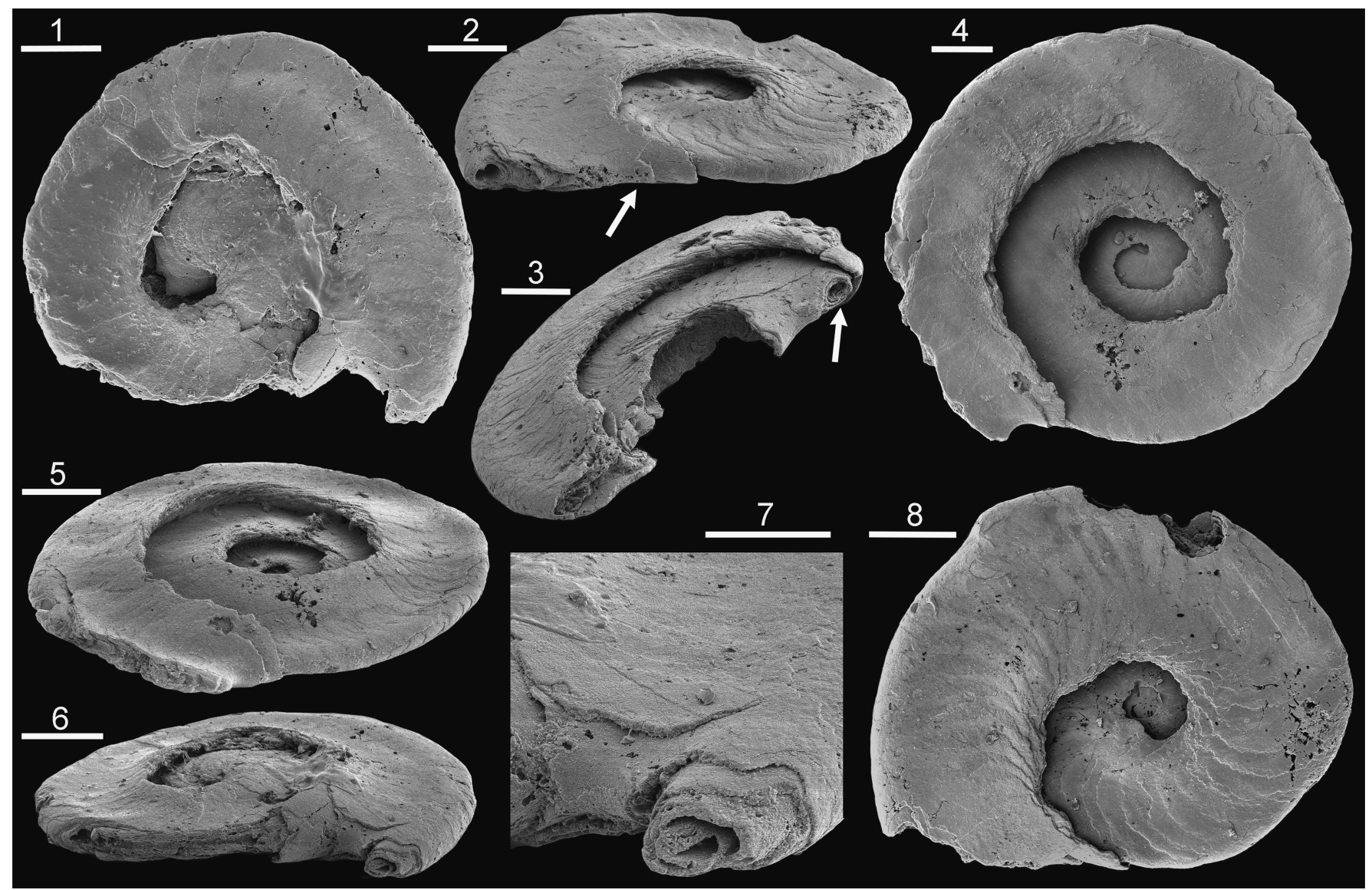

Figure 4. Tarimspira artemi n. sp., morphotype E, Henson Gletscher Formation, Cambrian Series 2, Stage 4; GGU sample 301354, southern Freuchen Land, North Greenland. (1) PMU 31849; (2, 8) PMU 31848, holotype, with arrow in (2) indicating growth lamellae extending from the base onto the lateral areas; (3) PMU 31850, broken specimen with circumperipheral cavity on penultimate whorl (arrow); (4, 5) PMU 31851; (6, 7) PMU 31852. (1-6, 8) Scale bars = 50 $\mu$ m; (7) scale bar $=25 \mu \mathrm{m}$.

Description.-The diagnostic sclerite (morphotype E) is laterally compressed, planispiral, bilaterally symmetrical and uniformly coiled through about one and a half to three whorls. The lateral surfaces are shallowly concave between the rounded periphery and the umbilical shoulders; spiral keels or carinae are absent. Adaxially, each lateral surface curves abruptly into a wide umbilicus formed as the growing sclerite overlaps earlier growth stages. The sutural area between the enveloping whorl and the earlier growth stage is deeply invaginated.

Externally, the sclerite is compact and appears to be solid. Growth lamellae slope obliquely abapically in from the lateral areas toward the axial plane in the direction of growth. Each growth lamella forms a continuous surface that curves from one lateral area to the other around the growing margin (base) of the sclerite (arrows in Figs. 4.2, 5.7). The growth lamellae produce regular transverse lines of growth that are concave toward the direction of growth (base) of the sclerite. Adjacent to the periphery, growth lamellae curve forward to form an elevation on the basal surface and appear to delimit a circumperipheral tubular canal (arrow in Fig. 4.3, 4.6, 4.7).

A single specimen similar to the holotype of Tarimspira zhejiangensis was found in the Henson Gletscher Formation of Løndal (Fig. 5.8), but it is tentatively referred to Tarimspira artemi in the absence of any other associated sclerites.
The associated sclerite (morphotype B2; Fig. 5.1-5.7, 5.9) is laterally compressed, bilaterally symmetrical, and typically open coiled through about a half to a full whorl; it is characterized by a prominent spiral carina with concave sides on each lateral surface close to the acute periphery (Fig. 5.2).

Etymology.-For Artem Kouchinsky in recognition of his contribution to the study of Cambrian faunas.

Materials.-PMU 31849-PMU 31857 from GGU sample 301354, southern Freuchen Land; PMU 31858 from GGU sample 271748, Løndal; PMU 31859 from GGU sample 218584, Løndal. Henson Gletscher Formation, Cambrian Series 2, Stage 4, North Greenland.

Remarks. - The diagnostic morphotype (morphotype E) is distinguished from Tarimspira plana (morphotype A) by its wider umbilici and lack of spiral keels around the periphery. The associated sclerite (morphotype B2) resembles sclerite morphotype B of Tarimspira zhejiangensis in terms of the prominent spiral carinae on the lateral surfaces, but most specimens are more openly coiled through less than a whorl (Fig. 5.5, 5.6). However, a single specimen from GGU sample 271748 in Løndal (Fig. 5.8), tentatively placed here, is more strongly 


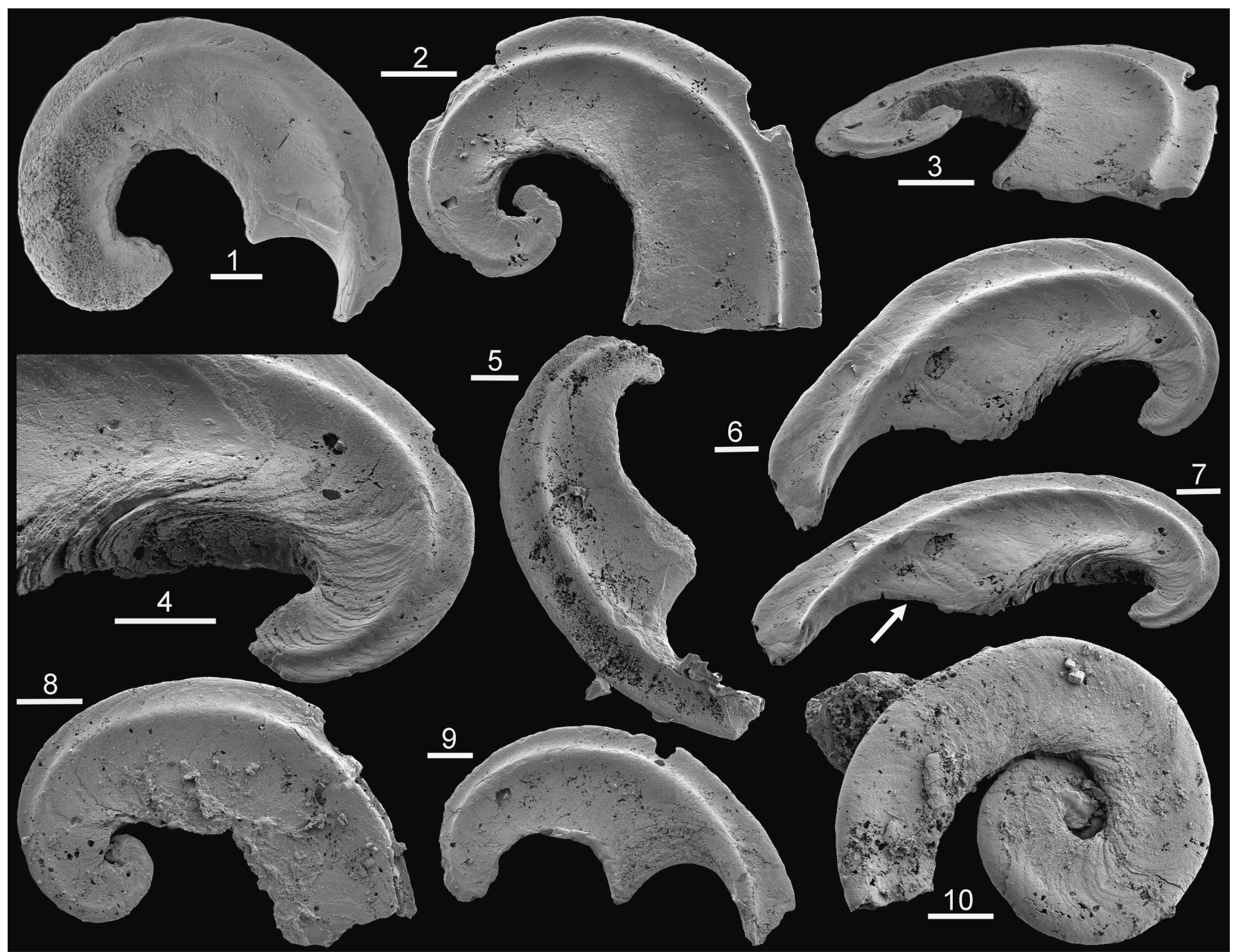

Figure 5. Tarimspira artemi n. sp., Henson Gletscher Formation, Cambrian Series 2, Stage 4; GGU sample 301354, southern Freuchen Land, North Greenland, unless stated. Morphotype B2 unless stated. (1) PMU 31853; (2, 3) PMU 31854; (4, 6, 7) PMU 31855, with arrow in (7) indicating the last deposited growth lamella extending from the base onto the lateral areas; (5) PMU 31856; (8) PMU 31858 from GGU sample 271748 Løndal, Peary Land, morphotype B; (9) PMU 31857; (10) PMU 31859 from GGU sample 218584, Henson Gletscher Formation, Henson Gletscher, southwest Peary Land, morphotype E. Scale bars $=50 \mu \mathrm{m}$.

coiled and therefore morphologically close to the holotype of Tarimspira zhejiangensis (Fig. 3.3).

The nature of the possible circumperipheral canal in Tarimspira artemi is obscure, not least since it is developed at the apex of the subperipheral elevation (Fig. 4.6). It may be an artifact produced by fracturing, or imperfect stacking of growth lamellae that fail to maintain contact just at their apices in the cone-in-cone structure (Fig. 4.7). Gaps between lamellae may also result in part from diagenesis or etching during preparation, as visible in the B2 morphotype (Fig. 5.4). Well-preserved specimens of this latter morphotype show no evidence of a canal (Fig. 5.6, 5.7). Spine-like sclerites (Fig. 3.5, morphotype D) assigned to Tarimspira zhejiangiensis by Steiner et al. (2003, fig. $3 \mathrm{~m}-\mathrm{O}$, s) seem to have a hollow core, but the separation of the spiral lamella suggests a diagenetic origin. However, Steiner et al. (2003, fig. 3f) described a circumperipheral central cavity extending from the base to the apex in morphotype C (Fig. 3.4), although the relationship of this to the basal part of the growth lamellae is unclear.

\section{Sclerite growth}

Sclerites of problematic organisms are diverse and abundant in assemblages of shelly fossils from the lower Cambrian (Bengtson, 2005; Rozanov et al., 2010; Kouchinsky et al., 2011, 2015), but Tarimspira sclerites differ from most described examples in their mode of secretion; they are constructed of abapically sloping lamellae (Figs. 1.5, 1.6, 3.7-3.9). Thus, the latest (basal) growth lamella was deposited externally; it overlies the previously formed lamella as it passes continuously from one lateral surface to the other around the abapical (basal) extremity (Fig. 1.5, arrow). As noted by Steiner et al. (2003) and Kouchinsky et al. (2015), this growth pattern indicates that the developing sclerites were rooted in an invagination in underlying soft tissues. Contemporaneous Cambrian sclerites such as lapworthellids (Devaere and Skovsted, 2017) and protoconodonts (Szianiawski, 1982, 1983, 1987, 2002; Bengtson, 1983; McIlroy and Szaniawski, 2000; Vannier et al., 2007) grew by the addition of lamellae on the inside of a hollow 
basal cavity, with deposition essentially upon papillae within the basal cavity. Both methods of growth increase the anchoring surface area of attachment relative to a simple, smaller, planar contact, which may enhance their defensive role or, in spinose grasping sclerites such as those of protoconodonts, even their maneuverability.

Comparable incremental growth around the lateral areas and across the base of sclerites occurs in paraconodonts such as Furnishina Müller, 1959, Prooneotodus Müller and Nogami, 1971, and Problematoconites Müller, 1959 (Murdock et al., 2013; Fig. 3.1, 3.2), although the acute spinose form and deep basal cavity of these paraconodonts find no morphological equivalence in Tarimspira. Instead of a basal cavity, the abapical termination of most sclerites of Tarimspira is rounded or wedge shaped (arrows in Fig. 1.5, 1.6; Fig. 5.1-5.7). The abapically concave shape of the growth lamellae as they cross the lateral areas of the sclerite in Tarimspira plana indicates that mineralizing tissue embraced the sclerite mainly on its lateral areas such that the earlier formed coil and umbilical areas in Tarimspira plana, together with most of the supra-apical surface, were probably exposed, at least periodically. While sclerite formation was within an invagination, the shape of the growth lamellae indicates that this pocket was likely formed as a cleft traversing either a papilla or a transverse ridge of secreting tissues.

The growing margin (abapical termination of the sclerite) is clearly visible in Tarimspira artemi $\mathrm{n}$. sp. (arrow in Fig. 4.2) and in sclerites with pronounced lateral spiral carinae (Fig. 5.1, 5.6, 5.9). Lateral ridges in the latter form a prominent transverse element that both reinforces the narrow sclerite and stabilizes its attachment in the soft tissues perpendicular to the otherwise narrow attachment surface along the plane of symmetry.

The prominent spiral lateral carinae of some Tarimspira sclerites (Fig. 5.1-5.9) are reminiscent of the lateral costae of distacodiform euconodont elements (Robison, 1981), but such structures are not typical of paraconodonts of the FurnishinaProoneotodus-Problematoconites morphological group. In Coelocerodontus Ethington, 1959, however, the tall, laterally compressed, thin-walled conical element may develop a prominent carina on either or both lateral surfaces and a pair of spiral keels on the supra-apical surface (Andres, 1988; Dong and Zhang, 2017). Specimens of Coelocerodontus from the early Ordovician of Sweden illustrated by Andres (1988, fig. 18) show a similar degree of curvature, rate of expansion, and ornamentation of spiral carinae to some sclerites of Tarimspira (Fig. 5.5, 5.6). Andres (1988) considered Coelocerodontus to be a paraconodont. Szaniawski (2015) suggested a separate group on the basis of its histology, but Dong and Zhang (2017) assigned it to the euconodonts. While the development of carinae perpendicular to the plane of symmetry in Tarimspira, Coelocerodontus, and distacodiform euconodont elements may suggest an evolutionary relationship, it is more likely that it reflects the common functions of strengthening the sclerite and increasing its anchorage in secreting soft tissues.

A basal cavity is not present in Tarimspira where the basal surface is usually protruding. There is evidence of the presence of a narrow spiral internal canal extending from the basal surface toward the apex in some sclerites (Fig. 4.6), as also discussed by Steiner et al. (2003), but the nature of the canal and, if present, its function are uncertain. A relationship to the basal cavity of members of the Furnishina-ProoneotodusProblematoconites morphological group might be suggested, although the initial growth stages of their elements do not show a comparable structure (Andres, 1988; Murdock et al., 2013).

\section{Scleritome}

Reconstruction of isolated sclerites into their original scleritomes is a vital step in the determination of the affinity of Cambrian problematic organisms. The special preservation offered by Lagerstätten has proved invaluable with regard to groups such as the chancelloriids (Bengtson and Collins, 2015) and halkieriids (Conway Morris and Peel, 1995). However, the reconstruction of many other organisms remains speculative and often a mental challenge, as demonstrated, for example, by the multiplated Trachyplax arctica Larsson, Peel, and Högstrom, 2009 that occurs in North Greenland in co-eval strata to those yielding the unrelated Tarimspira plana (Larsson et al., 2009).

Steiner et al. (2003) noted, but did not illustrate, clusters of similar sclerites of Tarimspira (as Fengzuella) zhejiangiensis in samples from the early Cambrian of South China (Fig. 3.4-3.6) but no recognizable scleritomes. However, they recognized three co-occurring sclerite morphotypes, here referred to as morphotypes B-D (Fig. 3; the tightly coiled sclerites of Tarimspira plana are designated as morphotype A). Coiled sclerites of morphotype B (Fig. 3.6) are rare. They are usually curved through slightly more than one revolution and more open coiled than the holotype of Fengzuella zhejiangensis $\mathrm{He}$ and Yu, 1992, refigured by Steiner et al. (2003, fig. 3a, b; Fig. 3.3, 3.6), but otherwise similar. Morphotype B sclerites carry a prominent spiral fold on each lateral area.

More than $85 \%$ of the specimens available to Steiner et al. (2003) are laterally compressed curved sclerites (length 410-1,340 $\mu \mathrm{m}$ ) with subparallel sides, a uniformly curved supra-apical surface, and a narrow base (morphotype C). These curved sclerites are coiled through less than half a whorl in lateral perspective (Fig. 3.4), with a median keel along the supra-apical surface, but lack spiral folds or ridges on the lateral areas (Steiner et al., 2003, fig. 3c). Narrow, straight or only slightly curved sclerites (morphotype D) are pointed and attain greater length than the curved sclerites. While they show the characteristic overlapping lamellae (Fig. 3.5), a cross section illustrated by Steiner et al. (2003, fig. 3s) indicates that this is a continuous spiral lamella rather than a series of discrete, stacked, cone-shaped lamellae. This difference in the mechanism of growth from morphotypes A-C makes it uncertain whether this sclerite belongs to the Tarimspira zhejiangiensis scleritome, although the two forms may represent end members in a morphological series. The sclerite in morphotypes $\mathrm{A}-\mathrm{C}$ is planispirally coiled, without any translation along the axis (Fig. 3). This coiling is tight in morphotype A but widely open coiled in morphotype $\mathrm{C}$. In the spine-like morphotype $\mathrm{D}$, there is a high rate of translation of the growing lamella along the axis of coiling with the result that the direction of growth of the sclerite approximates to the orientation of the coiling axis. Growth increase in morphotypes $\mathrm{A}$ and $\mathrm{B}$ is perpendicular to the axis of coiling. 
The increase in translation in morphotype $\mathrm{D}$ thus provides a mechanism for the development of a spinose sclerite with a possible grasping function. While its function may parallel the grasping function of sclerites of protoconodonts (Szaniawski, 1983) and panderodid eucondodonts (Sansom et al., 1995), the growth of morphotype D is constrained by the underlying protruding base characteristic of Tarimspira.

Greenland material assigned to Tarimspira artemi n. sp. includes two sclerite morphotypes. Curved to open-coiled sclerites (Fig. 3.7, morphotype B2; Fig. 5.1-5.9) are similar to the morphotype $\mathrm{B}$ sclerites of Tarimspira zhejiangensis (Figs. 3.3, 4.6) and carry a prominent spiral ridge on either side of the acute supra-apical keel. They occur together with tightly coiled sclerites in which coiling varies between two and three whorls, but which lack spiral ridges on the lateral areas (Fig. 3.9, morphotype E; Fig. 4). Sclerites of this type are not described in Tarimspira zhejiangensis, but both sclerite morphotypes B2 and $\mathrm{E}$ are recognized in material from the Emyaksin Formation of northern Siberia described by Kouchinsky et al. (2015, fig. 54), which is here assigned to Tarimspira artemi $\mathrm{n}$. sp. The single specimen of Tarimspira plana known from Greenland (Fig. 3.8, morphotype A; Fig. 1) is the same morphotype as the tightly coiled holotype (Yue and Gao, 1992) and specimens figured by Yang et al. (2015), but the former authors also illustrated an open-coiled morphotype with a lateral ridge similar to that noted here in morphotype B of Tarimspira zhejiangensis (Fig. 3.3, 3.6) and in Tarimspira artemi (morphotype B2; Fig. 5.1-5.9). Thus, at least partial scleritomes with distinctive sclerites can be recognized for each of the three described species of Tarimspira (T. plana, T. zhejiangensis, and T. artemi), although it is likely that these scleritomes contain other as yet unknown sclerite morphotypes.

The arrangement of individual sclerites and their precise function within the scleritomes are not known. Steiner et al. (2003) speculated that sclerites were closely packed in Tarimspira zhejiangensis with morphotypes B and C located laterally to morphotype D. Interpretation of the sclerites as dorsal armor might promote comparison with well-known but unrelated forms such as the early-middle Cambrian Wiwaxia Walcott, 1911 (Slater et al., 2017, fig. 14) or Halkieria Poulsen, 1967 (Conway Morris and Peel, 1995), although the morphology, method of formation, and composition of individual sclerites in the latter are fundamentally different (Smith, 2014; Zhang et al., 2015). Furthermore, there is little direct evidence concerning the orientation of sclerites in Tarimspira.

The present comparison with paracondonts in terms of sclerite growth promotes interpretation of the sclerites of Tarimspira as elements within an oropharyngeal feeding array (Donoghue et al., 2000), but there is little morphological similarity with known arrays. Andres (1988, fig. 17) presented a partial reconstruction of Coelocerodontus that might be applied to sclerites of morphotype B2, although these are more curved and less pointed than elements of Coelocerodontus and lack any obvious grasping function. However, this function may have been provided by the spine-like morphotype $D$. The position, orientation, and function of the tightly coiled sclerites of morphotypes $\mathrm{A}$ and $\mathrm{E}$ in such a reconstruction are unknown, but they may have had a crushing function deep in the pharynx in contrast to the grasping function of elements of the Furnishina-
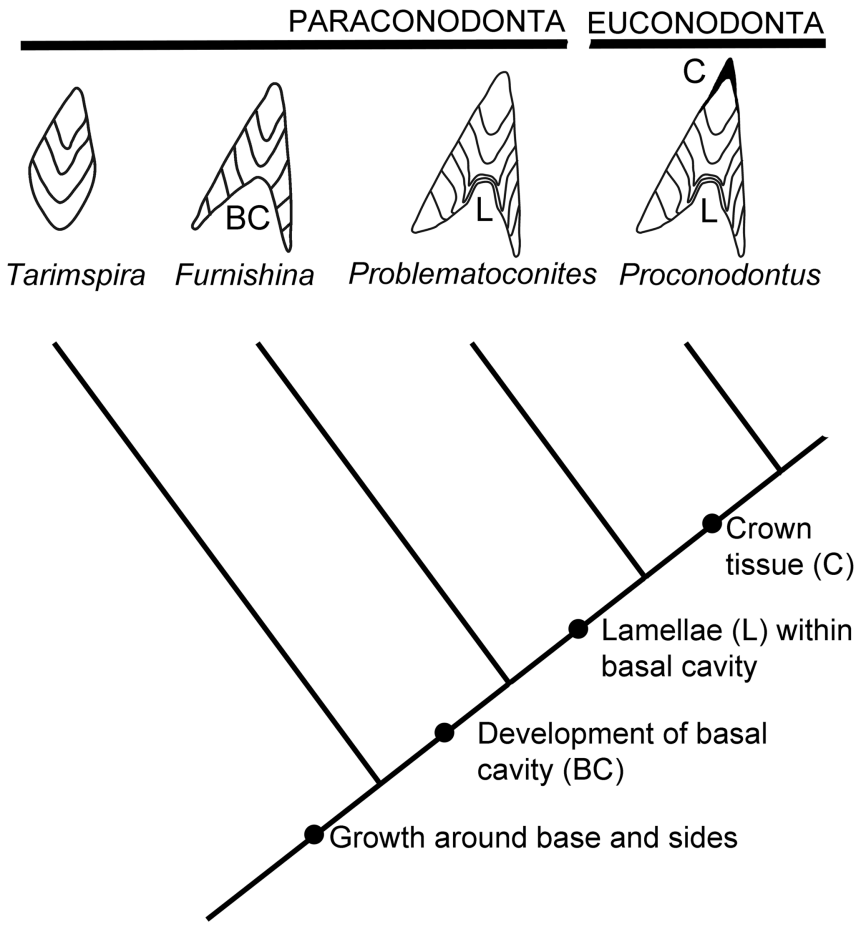

Figure 6. Proposed phylogenetic relationship between Tarimspira, paraconodonts, and euconodonts, based on Murdock et al. (2013, fig. 4).

Prooneotodus-Problematoconites type (Murdock et al., 2014). Whereas the basal (proximal) surface of sclerites probably would be located anteriorly in an elongate dorsal scleritome, with the curvature toward the posterior, no preferred single orientation can be assumed in oropharanygeal conodont arrays (Sansom et al., 1995; Szaniawski, 2002; Murdock et al., 2013).

\section{Systematic position}

The style of basal accretion with lateral overlap promotes comparison of Tarimspira with paraconodonts, but there is little similarity in terms of overall morphology between Tarimspira and fully developed paraconodont elements (Müller, 1959; Müller and Nogami, 1971; Andres, 1988; Müller and Hinz, 1991; Murdock et al., 2013), suggesting that the arrangement and function of the respective hard parts were disimilar. The morphological disparity may imply that the unusual method of accretion represents convergence in the method of growth, although a different but equally great range in morphology is seen when comparing other groups widely accepted as paraconodonts, namely the arcane westergaardodinids (Müller, 1959; Müller and Hinz, 1991) and the slender, curved, simple cones with a deep basal cavity extending almost to the tip seen in Furnishina, Prooneotodus, and Problematoconites (Fig. 3.1, 3.2).

Sclerites of Tarimspira lack a basal cavity, but the basal cavity in paraconodonts such as Furnishina, Prooneotodus, and Problematoconites is not developed until after elements attain a length of 100-300 $\mu \mathrm{m}$ (Andres, 1988, fig. 19; Murdock et al., 2013, fig. 2; Fig. 3.1). Prior to this stage, the characteristic basal overlap of the lateral areas by successive accreted layers closely resembles that seen in Tarimspira (Figs. 1.5, 5.4). Thus, Tarimspira sclerites could be interpreted as early ontogenetic stages of paraconodonts formed prior to the development of a basal cavity, although 
this interpretation is opposed by the large size of Tarimspira elements $(1.5 \mathrm{~mm})$ reported by Steiner et al. (2003) and the lack of direct evidence of later ontogenetic stages with a semblance of a basal cavity in any of the samples.

It is proposed that Tarimspira sclerites may reflect a stage in paraconodont evolution prior to the development of a basal cavity, suggesting a simple expansion of the model of paraconodont-euconodont evolution proposed by Murdock et al. (2013; Fig. 6). As concerns Tarimspira, however, the model is simplistic in that it is mainly based on the form of morphotypes A, B, and B2 (Fig. 3). Morphotype $\mathrm{C}$ is readily interpreted as a more open-coiled version of morphotype B2. Morphotype D of Tarimspira zhejiangensis is bizarre and may not belong to the scleritome, although greatly increased translation along the coiling axis is a feasible explanation of its growth form.

The interpretation of Tarimspira as a paraconodont is consistent with the geological record and pushes the known record of paraconodont vertebrates back into the early Cambrian. The oldest previously recognized paraconodonts, represented by Furnishina in the model of Murdock et al. (2013), are reported from the Ptychagnostus gibbus Biozone (uppermost Stage 5) of Cambrian Series 3 (Dong and Bergström, 2001; Dong et al., 2001; Kouchinsky et al., 2011; Dong and Zhang, 2017) whereas Tarimspira occurs in Cambrian Series 2 (Stage 4).

Paraconodonts thus encompass at least three distinct morphological groups: the Furnishina-Prooneotodus-Problematoconites slender cones with deep basal cavities, the westergaardodinids, and Tarimspira. The inhomogeneity suggests that the relationships of these groups of early vertebrates are poorly understood, adding substance to the demonstration of paraphyly by Murdock et al. (2013).

\section{Acknowledgments}

M. Steiner (Berlin) helped with literature from China. A. Kouchinsky (Stockholm) prepared some of the original scanning electron micrographs. B.J. Slater (Uppsala) is thanked for discussion and comments on the original manuscript. T.H.P. Harvey (Leicester) and D.J.E. Murdock (Oxford) are thanked for thoughtful reviews of the submitted manuscript.

\section{References}

Aldridge, R.J., Briggs, D.E.G., Clarkson, E.N.K., and Smith, M.P., 1986, The affinities of conodonts-New evidence from the Carboniferous of Edinburgh, Scotland: Lethaia, v. 19, p. 279-291.

Aldridge, R.J., Smith, M.P., Clarkson, E.N.K., and Clark, N.D.L., 1993, The anatomy of conodonts: Philosophical Transactions of the Royal Society of London, Series B, v. 340, p. 405-421.

Andres, D., 1988, Struktur, apparate und phylogenie primitiver conodonten: Paläontographica Abt. A, v. 200, p. 1-105.

Babcock, L.E., 1994a, Systematics and phylogenetics of polymeroid trilobites from the Henson Gletscher and Kap Stanton formations (middle Cambrian), North Greenland: Grønlands Geologiske Undersøgelse Bulletin, v. 169 p. 79-127.

Babcock, L.E., 1994b, Biogeography and biofacies patterns of middle Cambrian polymeroid trilobites from North Greenland: Palaeogeographic and palaeooceanographic implications: Grønlands Geologiske Undersøgelse Bulletin, v. 169 , p. $129-147$.

Bengtson, S., 1983, The early history of the Conodonta: Fossils and Strata, v. 15, p. 5-19.

Bengtson, S., 2005, Mineralized skeletons and early animal evolution, in Briggs, D.E.G., ed., Evolving Form and Function: Fossils and Development: New Haven, Yale Peabody Museum of Natural History, p. 101-124.
Bengtson, S., and Collins, D., 2015, Chancelloriids of the Cambrian Burgess Shale: Palaeontologia Electronica, v. 18, p. 1-67.

Blaker, M.R., and Peel, J.S., 1997, Lower Cambrian trilobites from North Greenland: Meddelelser om Grønland, Geoscience, v. 35, p. 1-145.

Blieck, A., Burrow, C.J., Schultze, H.P., Rexroad, C.B., Bultynck, P., and Nowlan, G.S., 2010, Fossils, histology, and phylogeny: Why conodonts are not vertebrates: Episodes, v. 33, p. 234-241.

Briggs, D.E.G., Clarkson, E.N.K., and Aldridge, R.J., 1983, The conodont animal: Lethaia, v. 16, p. 1-14.

Conway Morris, S., and Peel, J.S., 1995, Articulated halkieriids from the lower Cambrian of North Greenland and their role in early protostome evolution: Philosophical Transactions of the Royal Society of London Series B, v. 347, p. 305-358.

Devaere, L., and Skovsted, C.B., 2017, New early Cambrian sclerites of Lapworthella schodakensis from NE Greenland: Advancements in knowledge of lapworthellid taxonomy, sclerite growth and scleritome organization: Geological Magazine, v. 154, p. 1061-1072.

Ding, L., Zhang, L., Li, Y., and Dong, J., eds., 1992, The Study of the Late SinianEarly Cambrian Biota from the Northern Margin of the Yangtze Platform: Beijing, Scientific and Technical Documents Publishing House, 156 p.

Dong, X.-P., and Bergström, S.M., 2001, Middle and upper Cambrian protoconodonts and paraconodonts from Hunan, South China: Palaeontology, v. 44 , p. $949-985$.

Dong, X-P., and Zhang, H., 2017, Middle Cambrian through lowermost Ordovician conodonts from Hunan, South China: Journal of Paleontology, v. 91, no. S73, p. $1-89$.

Dong, X.-P., Repetski, J.E., and Bergström, S.M., 2001, A conodont biozonation for the middle Cambrian through lowermost Ordovician in Hunan, South China: Palaeoworld, v. 13, p. 252-255.

Donoghue, P.C.J., and Keating, J.N., 2014, Early vertebrate evolution: Palaeontology, v. 57, p. 879-893.

Donoghue, P.C.J., Purnell, M.A., and Aldridge, R.J., 1998, Conodont anatomy, chordate phylogeny and vertebrate classification: Lethaia, v. 31, p. 211-219.

Donoghue, P.C.J., Forey, P.L., and Aldridge, R.J., 2000, Conodont affinity and chordate phylogeny: Biological Reviews, v. 75, p. 191-251.

Ethington, R.L., 1959, Conodonts from the Ordovician Galina Formation: Journal of Paleontology, v. 33, p. 257-292.

Frykman, P., 1980, A sedimentological investigation of the carbonates at the base of the Brønlund Fjord Group (early-middle Cambrian), Peary Land, eastern North Greenland: Rapport Grønlands Geologiske Undersøgelse, v. 99, p. 51-55.

Geyer, G., and Peel, J.S., 2011, The Henson Gletscher Formation, North Greenland, and its bearing on the global Cambrian Series 2-Series 3 boundary: Bulletin of Geosciences, v. 86, p. 465-534

He, S., and Yu, G., 1992, The small shelly fossils from the Palaeocambrian Meishucunian Stage in western Zhejiang: Geology in Zhejiang, v. 8, p. 1-7 [in Chinese].

Higgins, A.K., Ineson, J.R., Peel, J.S., Surlyk, F., and Sønderholm, M., 1991, Lower Palaeozoic Franklinian Basin of North Greenland: Grønlands Geologiske Undersøgelse Bulletin, v. 160, p. 71-139.

Ineson, J.R., and Peel, J.S., 1997, Cambrian stratigraphy of North Greenland: Geology of Greenland Survey Bulletin, v. 173, p. 1-120.

Ineson, J.R., and Peel, J.S., 2011, Geological and depositional setting of the Sirius Passet Lagerstätte (early Cambrian), North Greenland: Canadian Journal of Earth Sciences, v. 48, p. 1259-1281.

International Commission on Zoological Nomenclature, 1999, International Code of Zoological Nomenclature (fourth edition): London, International Trust for Zoological Nomenclature, xxix $+306 \mathrm{p}$.

International Commission on Zoological Nomenclature, 2012, Amendment of Articles 8, 9, 10,21, and 78 of the International Code of Zoological Nomenclature to expand and refine methods of publication: Zootaxa, v. 3450, p. 1-7.

Kemp, A., and Nicoll, R.S., 1995, Protochordate affinities of conodonts: Courier Forschungsinstitut Senckenberg, v. 182, p. 235-245.

Kouchinsky, A., Bengtson, S., Runnegar, B., Skovsted, C., Steiner, M., and Vendrasco, M., 2011, Chronology of early Cambrian biomineralization: Geological Magazine, v. 149, p. 221-251.

Kouchinsky, A., Bengtson, S., Clausen, S., and Vendrasco, M., 2015, An early Cambrian fauna of skeletal fossils from the Emyaksin Formation, northern Siberia: Acta Palaeontographica Polonica, v. 60, p. 421-512.

Larsson, C., Peel, J.S., and Högström, A.E.S., 2009, Trachyplax arctica, a new multiplated problematic fossil from the lower Cambrian of North Greenland: Acta Palaeontologica Polonica, v. 54, p. 513-523.

Li, L., and Han, N., 1980, Discovery of Ordovician Trimelleridae (Brachiopoda) from western Zhejiang and its significance: Acta Palaeontographica Sinica, v. 19 , p. $8-21$.

McIlroy, M.D., and Szaniawski, H., 2000, A lower Cambrian protoconodont apparatus from the Placentian of southeastern Newfoundland: Lethaia, $v$ 33 , p. 95-102.

Müller, K.J., 1959, Kambrische Conodonten: Zeitschrift der Deutschen Geologischen Gesellschschaft, v. 111, p. 434-485. 
Müller, K.J., and Hinz, I., 1991, Upper Cambrian conodonts from Sweden: Fossils and Strata, v. 28, p. 1-153.

Müller, K.J., and Nogami, Y., 1971, Über den Feinbau der Conodonten: Memoirs of the Faculty of Sciences, University of Kyoto, Series of Geology and Mineralogy, v. 38, p. 1-87.

Murdock, D.J., Dong, X.-P., Repetski, J.E., Marone, F., Stampanoni, M., and Donoghue, P.C.J., 2013, The origin of conodonts and of vertebrate mineralized skeletons: Nature, v. 502, p. 546-549.

Murdock, D.J., Rayfield, E.J., and Donoghue, P.C.J., 2014, Functional adaptation underpinned the evolutionary assembly of the earliest vertebrate skeleton: Evolution \& Development, v. 16, p. 354-361.

Patte, E., 1929, Description de fossiles paléozoïques et mésozoïques recueillis par MM. Dussault et Fromaget en Extrême-Orient: Bulletin du Service géologique de l'Indochine, v. 18, p. 1-110.

Peel, J.S., 2017, The oldest pelmatozoan encrusted hardground and holdfasts from Laurentia (Cambrian Series 2-3): GFF, v. 139, p. 195-204.

Peel, J.S., and Sønderholm, M., 1991, Sedimentary basins of North Greenland: Grønlands Geologiske Undersøgelse Bulletin, v. 160, p. 1-164.

Peel, J.S., Streng, M., Geyer, G., Kouchinsky, A., and Skovsted, C.B., 2016, Ovatoryctocara granulata assemblage (Cambrian Series 2-Series 3 boundary) of Løndal, North Greenland: Australasian Palaeontological Memoirs, v. 49, p. 241-282.

Poulsen, C., 1967, Fossils from the lower Cambrian of Bornholm: Det Kongelige Danske Videnskabernes Selskab Matematisk-fysiske Meddelelser, v. 36 , no. 2, p. 1-48.

Pridmore, P.A., Banvick, R.E., and Nicoll, R.S., 1997, Soft anatomy and affinities of conodonts: Lethaia, v. 29, p. 317-328.

Robison, R.A., 1981, Supplement 2, Conodonta, in Moore, R.C., and Teichert, C., eds., Treatise on Invertebrate Paleontology, Part W: Boulder, Colorado, and Lawrence, Kansas, Geological Society of America (and University of Kansas Press), p. W1-W202.

Robison, R.A., 1984, Cambrian Agnostida of North America and Greenland, Part I, Ptychagnostidae: University of Kansas Paleontological Contributions Paper 109, p. 1-59.

Rozanov, A.Yu., et al., 2010, Fossils from the Lower Cambrian Stage Stratotypes: Russian Academy of Sciences Transactions of the Palaeontological Institute, 228 p. [in Russian].

Sansom, I.J., Armstrong, H.A., and Smith, M.P., 1995, The apparatus architecture of Panderodus and its implications for coniform conodont classification: Palaeontology, v. 37, p. 781-799.

Slater, B.J., Harvey, T.H.P., Guilbaud, R., and Butterfield, N.J., 2017, A cryptic record of Burgess Shale-type diversity from the early Cambrian of Baltica: Palaeontology, v. 60, p. 117-140.
Slater, B.J., Harvey, T.H.P., and Butterfield, N.J., 2018, Small carbonaceous fossils (SCFs) from the Terreneuvian (lower Cambrian) of Baltica: Palaeontology, doi:10.1111/pala.12350

Smith, M.R., 2014, Ontogeny, morphology and taxonomy of the soft-bodied Cambrian 'mollusc' Wiwaxia: Palaeontology, v. 57, p. 215-229.

Steiner, M., Li, G., Qian, Y., Zhu, M., and Erdtman, B., 2003, Lower Cambrian small shelly faunas from Zhejiang (China) and their biostratigraphical implications: Progress in Natural Science, v. 13, p. 852-860.

Szaniawski, H., 1982, Chaetognath grasping spines recognised among Cambrian protoconodonts: Journal of Paleontology, v. 56, p. 806-810.

Szaniawski, H., 1983, Structure of protoconodont elements: Fossils and Strata, v. 15 , p. $21-27$

Szaniawski, H., 1987, Preliminary structural comparisons of protoconodont, paraconodont, and euconodont elements, in Aldridge, R.J., ed., Palaeobiology of Conodonts: Chichester, Ellis Horwood, p. 35-47.

Szaniawski, H., 2002, New evidence for the protoconodont origin of chaetognaths: Acta Palaeontologia Polonica, v. 47, p. 405-419.

Szaniawski, H., 2015, New group of the early Palaeozoic conodont-like fossils: Estonian Journal of Earth Sciences, v. 64, p. 91-94.

Turner, S., Burrow, C.J., Schultze, H.P., Blieck, A., Reif, W.E., Rexroad, C. B., Bultynck, P., and Nowlan, G.S., 2010, False teeth: Conodontvertebrate phylogenetic relationships revisited: Geodiversitas, v. 32, p. 545-594.

Vannier, J., Steiner, M., Renvoisé, E., Hu, S., and Casanona, J., 2007, Early Cambrian origin of modern food webs: Evidence from predator arrow worms: Proceedings of the Royal Society Series B, v. 274, doi:10.1098/rspb.2006.3761

Walcott, C.D., 1911, Cambrian geology and palaeontology II. Middle Cambrian Merostomata: Smithsonian Miscellaneous Collection, v. 57, p. 17-40.

Yang, B., Steiner, M., and Kepp, H., 2015, Early Cambrian paleobiogeography of the Zhenba-Fangian Block (South China): Independent terrane or part of the Yangtze Platform? Gondwana Research, v. 28, p. 1543-1565.

Yue, Z., and Gao, L., 1992, Paleontology, biostratigraphy and geological significance of the early Cambrian protoconodonts and other skeletal microfossils from Aksu-Wushi Region, Xinjiang, China: Bulletin of the Institute of Geology, Chinese Academy of Geological Sciences, v. 23, p. 133-160 [in Chinese].

Zhang, Z., Smith, M.R., and Shu, D., 2015, A new reconstruction of the Wiwaxia scleritome, with data from Chengjiang juveniles: Scientific Reports, v. 5, 14810, doi: $10.1038 /$ srep 14810

Accepted 14 July 2018 